\title{
PENGARUH PENERAPAN STANDAR PRIVAT TERHADAP AKSES PRODUK INDONESIA KE PASAR GLOBAL
}

\section{The Effect of Private Standards Application to Access of Indonesian Products to Global Market}

\author{
Danar A. Susanto, Ari Wibowo dan Febrian Isharyadi \\ Pusat Penelitian dan Pengembangan Standardisasi, Badan Standardisasi Nasional \\ Gedung 1 BPPT, Lantai 12, JI. M.H.Thamrin no 8, Kebon Sirih, Jakarta Pusat 10340, DKI Jakarta, Indonesia \\ e-mail: danar@bsn.go.id
}

Diterima: 12 Oktober 2017, Direvisi: 8 Desember 2017, Disetujui: 11 Desember 2017

\begin{abstract}
Abstrak
Standar privat merupakan standar yang didesain oleh entitas di luar pemerintah, bisa dari entitas bisnis maupun organisasi non profit. Penerapan standar privat, sekarang semakin diakui dan meningkat yang dapat memberikan dampak positif maupun dampak negatif dalam perdagangan global. Tujuan dari penelitian ini adalah untuk mengetahui pengaruh penerapan standar privat terhadap akses produk Indonesia ke pasar global. Penelitian ini menggunakan pendekatan penelitian ex-post facto dengan analisis regresi dan korelasi untuk mengungkap hubungan antara penerapan standar privat terhadap nilai ekspor perdagangan dilihat dari variabel-variabel yang mempengaruhinya. Variabel-variabel yang digunakan untuk mengetahui pengaruh penerapan standar privat pada perdagangan global adalah tingkat kepedulian, pengetahuan, implementasi dan komitmen. Sedangkan nilai perdagangan diperoleh dari nilai perdagangan ekspor Indonesia. Penerapan standar privat mempunyai pengaruh yang sangat kuat terhadap nilai perdagangan global. Pengaruh dari penerapan dan pemenuhan terhadap persyaratan standar privat adalah memberikan nilai tambah dan posisi tawar dalam perdagangan global sehingga dapat memberikan keuntungan bagi perusahaan. Biaya teknis dan non teknis dari penerapan standar privat menjadi faktor perlu diperhatikan dan dibandingkan dengan keuntungan dari keberhasilan perdagangan dalam jangka panjang apabila suatu perusahaan bermaksud memasuki ceruk pasar yang didalamnya ada penerapan standar privat.
\end{abstract}

Kata kunci: standar privat, akses produk, kualitas produk, perdagangan global.

\begin{abstract}
Private standards are standards designed by entities outside of the government, whether from business entities or non-profit organizations. The application of private standards has been recognized and increased, which can have both positive and negative impacts on the global trade. The aim of this study is to determine the effect of private standards application on access of Indonesian products to global markets. This study uses an ex-post facto research approach with regression and correlation analysis to reveal the relationship between the application of private standards to trade exports seen from the variables that influence it. The variables used to determine the effect of the application of private standards on global trade are the level of awareness, knowledge, implementation and commitment. The value of trade is obtained from the value of Indonesian export trade. The application of private standards has a very strong influence on the value of global trade. The effect of the implementation and compliance with the requirements of private standards is to provide added value and bargaining positions in global trade so as to provide benefits to the company. The technical and non-technical costs of applying the private standards are a factor to be considered and compared to the benefits of long-term trading success if a company intends to enter a niche in which there is a private standard.
\end{abstract}

Keywords: private standards, product access, product quality, global trade.

\section{PENDAHULUAN}

Perkembangan standardisasi saat ini semakin cepat dan memegang peranan penting pada era globalisasi (Henson, 2008 ; Kaplinsky, 2010 ; Swann, 2010; Mangelsdorf, 2011). Perkembangan ini disebabkan karena standar menjadi permasalahan yang sangat mempengaruhi berbagai kebijakan publik maupun kepentingan publik (Spivak \& Brenner, 2001), hal ini selalu dikaitkan dengan internasionalisasi produk dan hubungan perdagangan. Standar sangat berhubungan dengan kepentingan konsumen, kesehatan dan keamanan, perlindungan lingkungan dan manajemen (Smith \& Riethmuller, 1999 ; Trienekens \& Zuurbier, 2008 ; Putri, 2010). 
Dinamika bidang standar dan kualitas juga berubah dengan cepat, di samping regulasi teknis, standar nasional dan standar internasional, saat ini terdapat penentu kualitas lain yaitu standar privat (Mc Cluskey, 2007 ; European Union External Action, 2010). Standar privat merupakan standar yang didesain oleh entitas di luar pemerintah, bisa dari entitas bisnis maupun organisasi non profit (Liu, 2009). Sedangkan menurut International Organization for Standardization (2010), standar privat didefinisan sebagai segala jenis standar yang dikembangkan oleh institusi non-pemerintah yang memiliki karakteristik tertentu yang terkait dengan aspek tatakelola (governance), pengembangan (development), dan keterkaitan berbagai pihak (stakeholder engagement).

Liu (2009) dan Shepherd \& Wilson (2013) mengemukakan bahwa standar privat di satu sisi dapat memberikan keuntungan dalam hal akses pasar, efisiensi manajemen, peningkatan kualitas produk sekaligus citra perusahaan, dan bahkan penurunan biaya usaha. Namun di sisi lain, penerapan standar privat dapat menjadi masalah terkait dengan kepemilikan dan kewenangan oleh otoritas tertentu yang terkadang tidak transparan dan belum tentu berdasar pada alasan ilmiah (scientific based reason). Selain itu, penerapan standar privat juga dapat membebani produsen tertentu, seperti small-holders dan produsen yang berada di luar area diberlakukannya standar privat (Schuster \& Maertens, 2015).

Standar privat juga dapat memiliki peran yang tumpang tindih dengan standar yang sudah ada, seperti standar nasional yang diterapkan pemerintah ataupun standar internasional yang berlaku. Disamping tumpang tindih dengan standar yang sudah ada, penerapan standar privat kemungkinan juga tumpang tindih dengan regulasi yang ditetapkan oleh negara tujuan ekspor.

Menurut Jaffee \& Henson (2004), aspek finansial dari produsen cenderung lebih baik ketika berpartisipasi dalam privat standar. Secara keseluruhan, dampak langsung dari berpartisipasi dalam privat standar adalah produsen mendapatkan harga dan keuntungan yang cenderung positif. Namun pada beberapa produsen, juga mendapatkan dampak negatif penerapan privat standar, yaitu pendapatan yang meningkat tidak mengimbangi biaya tambahan dan peningkatan biaya tenaga kerja dalam memenuhi persyaratan standar privat tersebut.

Namun demikian, dampak positif tidak langsung dapat lebih besar daripada dampak keuangan langsung dari berpartisipasi dalam penerapan standar privat antara lain kondisi bisnis produsen dapat ditingkatkan secara maksimal, kemungkinan mendapatkan keuntungan secara langsung dan cepat lebih besar, hubungan dengan pembeli jadi lebih baik, mendapatkan jaminan pemasaran dan peningkatan kualitas. Selain itu, dampak positif yang lain adalah dukungan teknis dan pelatihan dan peningkatan akses kredit ketika produsen berpartisipasi dalam standar privat (International Trade Centre, 2011).

Ekspor Indonesia didominasi oleh sektor non migas dengan persentase $82,79 \%$ (Kementrian Perindustrian, 2016). Beberapa sektor yang menjadi unggulan ekspor non migas adalah pertanian, kehutanan serta perikanan. Sektor ini menjadi unggulan karena asal produk (origin product) dari tiga sektor ini merupakan kekayaan alam Indonesia dan kuantitas produk sektor ini berlimpah. Karena kelebihan-kelebihan sektor tersebut, pada saat perdagangan ekspor kemungkinan akan terkena dampak dari penerapan standar privat yang diterapkan oleh pembeli, retail, asosiasi bisnis bahkan LSM.

Dampak penerapan standar ini dapat berdampak positif namun juga negatif. Melihat fakta tersebut, tujuan penelitian untuk mengetahui pengaruh standar privat terhadap akses produk indonesia ke pasar global.

\section{TINJAUAN PUSTAKA}

\subsection{Perkembangan Standar Privat}

Standar yang dimiliki oleh sebuah produk akan menentukan karakteristik dari produk tersebut. Standar produk memegang peranan penting dalam pasar untuk membedakan barang yang satu dengan yang lain. Terdapat dua macam pembedaan terhadap suatu barang yang disebabkan dengan adanya suatu standar pada barang yaitu pembedaan barang secara vertikal dan pembedaan barang secara horizontal.

Pembedaan barang secara vertikal mengakibatkan barang yang satu lebih bagus dibandingkan yang lain. Sedangkan pembedaan secara horizontal tidak mengakibatkan suatu barang lebih bagus dari yang lain (UNTAC/WTO, 2005).

Standar dibedakan menjadi beberapa kategori pengelompokan. Kategori standar dibagi menjadi 5 perspektif, yaitu standar internasional, standar nasional, standar asosiasi, standar company dan standar individual (Verman, 1973). Berdasarkan penerapannya, standar dibedakan mejadi standar sukarela (voluntary standard) dan standar wajib (mandatory standard). Berdasarkan 
kategori organisasi penerap, standar dibedakan menjadi standar publik dan standar privat.

Standar publik dan standar privat dapat diberlakukan secara wajib (mandatory) dan sukarela (voluntary). Pada barang yang diterapkan standar wajib, hanya barang yang memenuhi standar yang dapat beredar dipasar.
Sedangkan barang yang dikenakan standar sukarela, barang yang tidak memenuhi standar dapat beredar dipasar juga (UNTAC/WTO, 2005). Tabel 1 membedakan antara standar wajib dan sukarela dan antara standar yang ditetapkan oleh badan publik dan swasta.

Tabel 1 Pengelola dan penerapan standar.

\begin{tabular}{|c|c|c|}
\hline \multirow{2}{*}{ Penerapan } & \multicolumn{2}{|r|}{ Pengelolaan } \\
\hline & Publik & Privat/ Swasta \\
\hline Wajib (Mandatory) & Regulasi & Legally - mandated private standards \\
\hline Sukarela (Voluntary) & Standar sukarela & Standar sukarela \\
\hline
\end{tabular}

Standar privat diwakili oleh kolom paling kanan, standar ini ditetapkan (dibuat) oleh entitas komersil atau swasta non-komersil, termasuk perusahaan, organisasi industri, organisasi nonpemerintah (NGO) dan lain-lain. Standar privat akan menjadi sukarela tergantung pada bentuk dan pengaruh dari suatu entitas yang mengadopsi standar tersebut, adopsi standar ini menjadi suatu kebutuhan yang diterapkan oleh entitas yang lain (Brunsson \& Jacobsson, 2002).

Standar privat jika diadopsi oleh swasta dan jika penerapannya menjadi wajib oleh pelaku pasar yang dominan (driven supply chains), maka penerapan oleh entitas lain yang akan masuk dalam pasar tersebut harus memenuhinya, namun tidak ada hukuman dari ketidakpatuhan akan penerapan standar tersebut.

Entitas tersebut hanya tidak bisa berpartisipasi dalam pasar yang menerapkan standar privat tersebut. Sedangkan standar privat yang diadopsi oleh suatu negara dan diregulasikan, maka pemenuhan standar adalah wajib dan setiap produsen serta eksportir harus mengacu pada regulasi standar privat tersebut.

Istilah standar privat sudah berlangsung sejak tahun 1990-an, seiring dengan peningkatan peran perdagangan internasional dalam kegiatan ekonomi dunia (Sukesi dkk, 2013). Munculnya semangat dalam menggunakan standar privat didominasi oleh globalisasi, liberalisasi perdagangan, perubahan preferensi konsumen, dan kemajuan informasi dan teknologi (IT). Dalam penerapannya, jenis dan kategori standar privat sangat beragam, tergantung pada sasaran, cakupan, kelebihan, serta kekurangannya. Oleh karena itu, standar privat tidak bisa dikategorikan sebagai jenis standar yang homogen (Liu, 2009).

Antara standar privat yang satu dengan yang lain berbeda secara signifikan tergantung pada tujuan, ruang lingkup, supplier, jenis perusahaan, daerah, jenis organisasi yang memiliki dan yang membutuhkan mereka. Secara garis besar, target standar privat ada dua kategori, yaitu standar antar bisnis dengan entitas bisnis lainnya dan konsumen akhir atau bisnis ke konsumen. Sebagian besar standar keamanan pangan, standar proses pertanian adalah skema standar B2B (business to business). Sebaliknya, kualitas produk dan standar etika biasanya termasuk dalam kategori B2C (business to customers). Salah satu Standar $\mathrm{B} 2 \mathrm{C}$ adalah melalui penggunaan label yang ditempelkan pada produk

Beberapa contoh standar privat yang sudah diterapkan antara lain COLEACP, Tesco's Nature Choice, British Retail Consortium (BRC), Carrefour's Filière Qualité, GlobalGAP, The International Confederation of Free Trade Union (ICFTU), Fair-Trade Labeling Organisation (FLO) dan The Sustainable Agricultural Network (SAN). Sektor perikanan merupakan salah satu sektor yang peningkatan standar privatnya cukup signifikan, antara lain Thai Quality Shrimps, GAP Thailand, COC - Certified Thai Shrimps, IFOAM, Agriculture Biologique, Qualite Aquaculture de France, Shrimp Seal of Quality Bangladesh, China GAP, The Responsible Fishing Scheme (Washington \& Ababouch, 2011).

\subsection{Peran Standar Privat dalam Perdagangan Internasional}

Penerapan standar privat pada sebuah entitas atau buyer memiliki posisi tawar yang cukup kuat dalam menentukan persyaratan yang diminta kepada para pemasok dalam hal standar tertentu itu tidak hanya dalam hal harga dan spesifikasi produk, namun juga dalam persyaratan produksi, pemprosesan dan transportasi. Banyak pembeli atau buyer memiliki spesifikasi standar mereka sendiri yang dikomunikasikan semata-mata untuk pemasok mereka dimana pemasok lain hanya 
memiliki sedikit pengetahuan terkait standar tersebut. Namun, untuk kategori standar tertentu, terutama yang terkait dengan keamanan pangan, pembeli menerapkan sebuah standar sebagai sebuah kelompok dan memerlukan audit pihak ketiga dan sertifikat.

Perkembangan tingkat pendidikan, urbanisasi dan gaya hidup menyebabkan perubahan pola dan paradigma kualitas. Sebagai contoh adalah kualitas makanan yang dianggap menjadi jauh lebih penting. Aspek kualitas makanan dituntut mulai dari yang berkaitan dengan proses produksi dan perdagangan yang melibatkan masyarakat dan lingkungan, berbagai isu-isu sosial, lingkungan atau budaya seperti perlakuan terhadap pekerja, dampak lingkungan dan kesejahteraan karyawan sedikit banyak juga turut menyumbang dalam perkembangan privat standar. Beberapa Lembaga Swadaya Masyarakat (LSM) telah membuat sebuah standar yang berhubungan dengan pekerja yang terlibat dalam proses produksi dimana perusahaan dapat memilih untuk mengadopsi untuk memenuhi standar tersebut.

Penerapan standar privat semakin diakui dan memiliki dampak yang potensial dalam perdagangan. Standar privat seringkali melampaui persyaratan dalam regulasi suatu negara. Pemenuhan standar privat seringkali memerlukan biaya yang tinggi kepada supplier dan eksportir. Biaya tersebut timbul dari investasi tetap dalam menyesuaikan proses produksi dan penyesuaian fasilitas, personil dan biaya manajemen untuk menerapkan sistem kontrol serta biaya penilaian kesesuaian dari standar tersebut. Biaya ini cenderung lebih besar bagi eksportir di negara-negara dimana standar privat tersebut kurang berkembang dengan baik (Jaffee \& Henson, 2004).

Sebagai standar sukarela, standar privat dapat berbeda antar negara. Hal ini dapat menjadi penghalang yang efektif dalam perdagangan, seperti perusahaan, company group, bahkan sampai tingkat petani yang tidak mampu memenuhi standar privat tersebut (Fulponi, 2006). Sebagai contoh adalah penerapan Forest Stewardship Council (FSC) yang tidak akan mensertifikasi lahan hutan tanaman industri $(\mathrm{HTI})$ yang dikonversi setelah tahun 1994 (Jati, 2017).

Bagi perusahaan di Indonesia yang merupakan afiliasi dari perusahaan multinasional, standar privat mungkin tidak terlalu menjadi masalah. Perusahaan multinasional biasanya telah menjadi bagian dari kelompok yang mengatur standar privat, sehingga perusahaan afiliasinya secara otomatis akan memenuhi standar tersebut melalui penerapan kebijakan mutu korporat multinasional itu sendiri. Tetapi bagi perusahaan-perusahaan lokal Indonesia, tantangan akan dirasakan jauh lebih besar (European Union External Action, 2010).

\subsection{Faktor-Faktor yang Mempengaruhi Penerapan Standar Privat pada Perdagangan Global}

Variabel-variabel yang digunakan untuk mengetahui pengaruh penerapan standar privat pada perdagangan global ditinjau dari tingkat kepedulian (awareness), pengetahuan (knowledge), implementasi (implementation) dan komitmen (commitment). Hal ini mengacu pada penelitian-penelitian yang telah dilakukan sebelumnya.

Faktor-faktor yang mempengaruhi keberlanjutan penerapan GMP dan SSOP pengolahan fillet ikan antara lain disebabkan faktor internal seperti rendahnya tingkat pengetahuan dan kurangnya pemahaman, faktor eksternal seperti kurangnya sosisalisasi, kurangnya fasilitas air bersih, es dan rantai dingin, kurangnya pembinaan, lemahnya pengawasan dan penegakan hukum, dan faktor karakteristik inovasi seperti rendahnya permintaan pasar, rendahnya keuntungan yang diperoleh, dan rumitnya penerapan GMP dan SSOP (Yuwono, Zakaria, \& Panjaitan, 2012).

Pemahaman pelaku usaha terhadap materi SNI (sukarela) keberadaan lembaga penunjang (lembaga sertifikasi produk, supervisi/pengawas mutu) menjadi faktor penentu utama bagi perusahaan dalam menerapkan SNI yang ada (Resnia, Wicaksena, \& Salim, 2015). Sedangkan faktor yang mempengaruhi UKM dalam menerapkan standar secara konsisten adalah komitmen, permintaan konsumen, inovasi dan nilai penjualan (Susanto, Isharyadi, \& Aliyah, 2016). Sedangkan dalam mengukur kinerja ekspor, digunakan variabel antara lain harga produk perikanan di Indonesia, produksi, nilai tukar, dan hambatan non-tarif (Lambaga, 2009).

\subsection{Regresi dan Korelasi}

Regresi merupakan suatu alat ukur yang dapat digunakan untuk mengukur ada atau tidaknya hubungan antarvariabel. Analisis regresi mempelajari hubungan yang dinyatakan dalam persamaan matematika yang menyatakan hubungan fungsional antara variabel-variabel. Hubungan fungsional antara satu variabel prediktor dengan satu variabel kriterium disebut analisis regresi sederhana (tunggal), sedangkan 
hubungan fungsional yang lebih dari satu variabel disebut analisis regresi ganda. Dengan demikian maka melalui analisis regresi, peramalan nilai variabel terikat pada nilai variabel bebas lebih akurat pula. Persamaan regresi linier dari $Y$ terhadap $X$ dirumuskan sebagai berikut:

$\mathrm{Y}=\mathrm{a}+\mathrm{b} \mathrm{X}$

Keterangan:

$\mathrm{Y}=$ variabel terikat

$\mathrm{X}=$ variabel bebas

$a=$ intersep

$\mathrm{b}=$ koefisien regresi/slop

Dalam menelaah adanya ketergantungan anatra dua peubah $\mathrm{X}$ dan $\mathrm{Y}$ atau diantara dua peubah/faktor, perlu dilakukan suatu ukuran ketergantungan yaitu analisis korelasi (Sudjana, 2002). Dalam teori probabilitas dan statistika, korelasi, juga disebut koefisien korelasi, adalah nilai yang menunjukkan kekuatan dan arah hubungan linier antara dua peubah acak (random variable).

Salah satu jenis korelasi yang paling populer adalah koefisien korelasi momen-produk Pearson, yang diperoleh dengan membagi kovarians kedua variabel dengan perkalian simpangan bakunya. Untuk melakukan interpretasi kekuatan hubungan antara dua variabel dilakukan dengan melihat angka koefisien kolerasi hasil perhitungan dengan menggunakan interpretasi nilai $r$ adalah sebagai berikut:

0 : Tidak ada korelasi antara dua variable

$>0-0,25$ : Korelasi sangat lemah

$>0,25-0,5:$ Korelasi cukup

$>0,5-0,75$ : Korelasi kuat

$>0,75-0,99$ : Korelasi sangat kuat

1 : Korelasi sempurna (Sudjana, 2002).

\section{METODE PENELITIAN}

Penelitian ini menggunakan pendekatan penelitian ex-post facto untuk mengungkap hubungan antara penerapan standar privat terhadap nilai ekspor perdagangan. Variabelvariabel yang digunakan untuk mengetahui pengaruh penerapan standar privat pada perdagangan global ditinjau dari tingkat kepedulian (X1), faktor pengetahuan (X2), faktor implementasi (X3) dan faktor komitmen (X4). Sedangkan nilai perdagangan $(Y)$ diperoleh dari nilai perdagangan ekspor Indonesia untuk produk prioritas yang dipilih.
Penelitian ini mempunyai ruang lingkup bidang perikanan, kehutanan dan pertanian. Pada masing-masing sektor tersebut ditentukan produk prioritas berdasarkan nilai perdagangan ekspor, produk unggulan dan renstra kementerian terkait. Berdasarkan kriteria yang telah ditentukan tersebut, diperoleh produk prioritas bidang pertanian adalah minyak kelapa sawit dan pertanian pangan organik (padi, buah dan sayuran). Produk priorotas bidang kehutanan adalah plywood dan kayu gergajian. Sedangkan produk prioritas bidang perikanan adalah udang dan tuna.

Metode pengumpulan data dalam penelitian ini dilakukan dengan wawancara ke perusahaan yang melakukan eskpor produk prioritas yang telah dipilih. Wawancara dilakukan dengan bantuan kuesioner. Pengambilan sampel dilakukan dengan pendekatan purposive random sampling dengan memperhatikan stratifikasi ruang lingkup bidang penelitian.

Setiap bidang memiliki kesempatan dan proporsi yang sama untuk diambil sampel secara acak. Sampel penelitian ini adalah 39 responden yang melakukan ekspor sesuai dengan produk prioritas dengan studi kasus di wilayah Balikpkapan, Samarinda, Padang, Manado, Bekasi, Depok dan Bogor. Metode analisa yang digunakan dalam penelitian ini menggunakan metode analisis regresi dan korelasi untuk mengetahui ada atau tidak adanya hubungan dan besarnya hubungan antara penerapan standar privat dengan perdagangan eskpor.

\section{HASIL DAN PEMBAHASAN}

Analisis regresi dan korelasi digunakan untuk mengetahui hubungan antara faktor penerapan standar privat terhadap nilai perdagangan ekspor. Sebelum dilakukan analisis regresi dan korelasi dilakukan uji asumsi klasik untuk memberikan kepastian bahwa persamaan regresi yang didapatkan memiliki ketepatan dalam estimasi, tidak bias dan konsisten.

\section{a. Uji Asumsi Klasik Model Regresi}

Uji yang dilakukan antara lain adalah uji multikolinieritas, heteroskedastisitas, normalitas dan autokorelasi.

\section{b. Uji Asumsi Klasik Multikolinieritas}

Uji asumsi klasik multikolinieritas digunakan untuk mengukur tingkat asosiasi (keeratan) hubungan/pengaruh antar variabel bebas tersebut melalui besaran koefisien korelasi (r). Uji ini menguji apakah model regresi ditemukan 
adanya korelasi antar variabel bebas (independent). Model regresi yang baik seharusnya tidak terjadi korelasi antara variabel bebas (tidak terjadi multikoliearitas). Jika variabel bebas saling berkorelasi, maka variabel-variabel ini tidak ortogonal.

Berdasarkan pengolahan data diperoleh nilai toleransi dan VIF sebagai berikut:

Tabel 2 Hasil uji multikolinearitas.

\begin{tabular}{lcc}
\multirow{2}{*}{$\begin{array}{c}\text { Variabel } \\
\text { Independen }\end{array}$} & \multicolumn{2}{c}{ Statistik Kolinearitas } \\
\cline { 2 - 3 } Kepedulian & Toleransi & VIF \\
\hline Pengetahuan & 0,506 & 1,977 \\
\hline implementasi & 0,668 & 1,497 \\
\hline Komitmen & 0,597 & 1,675 \\
\hline
\end{tabular}

\section{c. Uji Asumsi Klasik heteroskedastisitas.}

Dalam persamaan regresi berganda perlu diuji mengenai sama atau tidak varians dari residual dari observasi yang satu dengan observasi lainnya. Jika residual mempunyai varians yang sama, disebut homoskedastisitas dan jika variansinya tidak sama disebut terjadi heteoskedastisitas. Persamaan regresi yang baik jika tidak terjadi heteroskedastisitas. Metode yang digunakan untuk uji heteroskedastisitas adalah dengan korelasi Spearman's rho, yaitu mengkorelasikan variabel independen dengan nilai unstandardized residual. Pengujian menggunakan tingkat signifikansi 0,05 dengan uji 2 sisi. Dasar pengambilan keputusan pada uji heteroskedastisitas adalah sebagai berikut:

- Jika nilai signifikansi lebih besar dari 0,05, kesimpulanya adalah tidak terjadi heteroskedastisitas.

- Jika nilai signifikansi lebih kecil dari 0,05, kesimpulanya adalah terjadi heteroskedastisitas.

Tabel 3 Uji asumsi klasik heteroskedastisitas.

\begin{tabular}{lc}
\hline Variabel Independen & Nilai signifikansi \\
\hline Kepedulian & 0,130 \\
\hline Pengetahuan & 0,953 \\
\hline implementasi & 0,921 \\
\hline Komitmen & 0,278 \\
\hline
\end{tabular}

Berdasarkan tabel di atas, semua variabel bebas dengan unstandardized residual memiliki nilai signifikansi lebih dari 0,05 yang menunjukkan bahwa tidak terjadi heteroskedastisitas pada model regresi.

188

\section{d. Uji Asumsi Klasik Normalitas}

Pengujian asumsi normalitas untuk menguji data variabel bebas $(\mathrm{X})$ dan variabel terikat $(\mathrm{Y})$ pada persamaan regresi yang dihasilkan, apakah berdistribusi normal atau berdistribusi tidak normal. Jika distribusi data normal, maka analisis data dan pengujian hipotesis digunakan statistik parametrik. Dasar pengambilan keputusan pada uji normalitas adalah sebagai berikut:

- Jika nilai signifikansi lebih besar dari 0,05, kesimpulanya adalah tidak normal.

- Jika nilai signifikansi lebih kecil dari 0,05, kesimpulanya adalah normal.

Tabel 4 Hasil uji asumsi kalsik normalitas.

\begin{tabular}{lcc}
\multirow{2}{*}{$\begin{array}{c}\text { Variabel } \\
\text { Independen }\end{array}$} & \multicolumn{2}{c}{ Nilai signifikansi } \\
\cline { 2 - 3 } & $\begin{array}{c}\text { Kolmogorov- } \\
\text { Smirnov }\end{array}$ & Shapiro-Wilk \\
\hline Kepedulian & 0,000 & 0,000 \\
\hline Pengetahuan & 0,000 & 0,001 \\
\hline implementasi & 0,002 & 0,001 \\
\hline Komitmen & 0,000 & 0,000 \\
\hline
\end{tabular}

Berdasarkan data pada tabel di atas, semua variabel bebas memiliki nilai signifikansi kurang dari 0,05 yang menunjukkan bahwa data dalam penelitian ini memenuhi kaidah normalitas.

\section{e. Uji Asumsi Klasik Autokorelasi}

Persamaan regresi yang baik adalah tidak memiliki masalah autokorelasi. Jika terjadi autokorelasi maka persamaan tersebut menjadi tidak baik atau tidak layak dipakai prediksi. Ukuran dalam menentukan ada tidaknya masalah autokorelasi dengan uji Durbin-Watson (DW), dengan ketentuan sebagai berikut:

- Terjadi autokorelasi positif jika DW di bawah 2 (DW < -2).

- Tidak terjadi autokorelasi jika DW berada di antara -2 dan +2 atau $-2<\mathrm{DW}+2$.

Berdasrkan hasil uji asumsi klasik autokorelasi dengan SPSS, nilai dari DurbinWatson sebesar 1,438 yang menunjukkan bahwa tidak terjadi autokorelasi karena nilai DW berada di antara -2 dan +2 .

\section{f. Analisis Regresi dan Korelasi}

Analisis regresi dan korelasi digunakan untuk mengetahui ada atau tidak adanya hubungan dan besarnya hubungan antara penerapan standar privat dengan perdagangan eskpor. 
Tabel 5 Hasil analisis regresi.

\begin{tabular}{lc}
\multicolumn{1}{c}{ Kategori } & Nilai \\
\hline $\mathrm{R}$ & 0,891 \\
\hline $\mathrm{R}$ Square & 0,795 \\
\hline Adjusted R Square & 0,771 \\
\hline $\mathrm{F}$ & 32,907 \\
\hline Signifikansi & 0,000 \\
\hline
\end{tabular}

Berdasarkan tabel di atas diperoleh angka Adjusted $R$ Square sebesar 0,771 atau $(77,1 \%)$. Hal ini menunjukkan bahwa persentase sumbangan pengaruh variabel independen (kepedulian, pengetahuan, implementasi dan komitmen) terhadap variabel dependen (nilai perdagangan ekspor) sebesar $77,1 \%$. Variasi variabel independen yang digunakan dalam model mampu menjelaskan sebesar $77,1 \%$ variasi variabel dependen, sedangkan sisanya sebesar 23,9\% dipengaruhi atau dijelaskan oleh variabel lain yang tidak dimasukkan dalam model penelitian ini. Adjusted $R$ Square adalah nilai $R$ Square yang telah disesuaikan, nilai ini selalu lebih kecil dari $R$ Square dan angka ini bisa memiliki harga negatif. Menurut Santoso (2001) bahwa untuk regresi dengan lebih dari dua variabel bebas digunakan Adjusted $R$ Square sebagai koefisien determinasi.

Uji koefisien regresi secara bersamasama (Uji F) digunakan untuk mengetahui apakah variabel independen secara bersamasama berpengaruh secara signifikan terhadap variabel dependen (ekspor). Disamping itu untuk mengetahui apakah model regresi dapat digunakan untuk memprediksi variabel dependen atau tidak. Signifikan berarti hubungan yang terjadi dapat berlaku untuk populasi (dapat digeneralisasikan). Tahap-tahap untuk melakukan uji $\mathrm{F}$ yaitu merumuskan hipotesis terlebih dahulu sebagai berikut:

- Ho : tidak ada pengaruh secara signifikan antara semua faktor independen secara bersama-sama terhadap variabel dependen.

- Ha : ada pengaruh secara signifikan antara semua faktor independen secara bersamasama terhadap variabel dependen (ekspor).

Dengan menggunakan tingkat keyakinan $95 \%$, a $=5 \%$, df 1 (jumlah variabel-1) $=4$, dan df $2(\mathrm{n}-\mathrm{k}-1)$ atau 39-4-1 = 34 ( $\mathrm{n}$ adalah jumlah kasus dan $\mathrm{k}$ adalah jumlah variabel independen), hasil diperoleh untuk $F$ tabel sebesar 2,64. Kriteria pengujian adalah sebagai berikut:

- Ho diterima bila $F$ hitung $<F$ tabel
- Ho ditolak bila $F$ hitung $>F$ tabel

Nilai $F$ hitung > F tabel $(32,907>2,64)$, maka Ho ditolak yang berarti ada pengaruh secara signifikan antara semua faktor independen secara bersama-sama terhadap variabel dependen (ekspor).

Analisis korelasi digunakan untuk mengetahui tingkatan atau besaran hubungan antara kepedulian, pengetahuan, implementasi dan komitmen secara bersama-sama terhadap variabel dependen (ekspor). Berdasarkan Tabel 3 diperoleh angka koefisien $\mathrm{R}$ sebesar 0,891 . Hal ini menunjukkan bahwa terjadi hubungan yang sangat kuat antara kepedulian, pengetahuan, implementasi dan komitmen dalam penerapan standar privat terhadap peningkatan nilai perdagangan ekspor.

Berdasarkan analisis deskriptif, 84\% responden menyatakan bahwa pembeli (buyer) yang ada di negara tujuan ekspor Indonesia meminta standar privat. Dalam penerapan standar privat, $91 \%$ responden menyatakan bahwa penerapan standar privat memberikan keuntungan bagi perusahaan, hal ini diperkuat dengan $78 \%$ responden yang menyatakan bahwa penerapan standar privat memberikan nilai tambah dan posisi tawar dalam perdagangan global.

Pengetahuan terhadap penerapan standar privat oleh perusahaan yang didukung oleh komitmen dan kepedulian seluruh pihak yang terkait untuk mengimplementasikan standar privat akan menentukan keberhasilan ekspor produk ke konsumen dalam pedagangan global yang menerapkan standar privat tersebut. Dalam hal ini, pengetahuan akan standar privat adalah kunci awal dari keberhasilan perdagangan global. Namun sebaliknya, apabila perusahaan tidak mempunyai pengetahuan akan standar privat dan bermaksud melakukan perdagangan dalam ceruk pasar tersebut, maka keberhasilan perdagangan menjadi sangat kecil.

Hal ini selaras dengan yang disampaikan oleh Liu (2009) dan Shepherd \& Wilson (2013) bahwa standar privat dapat memberikan keuntungan dalam hal akses pasar, efisiensi manajemen, peningkatan kualitas produk sekaligus citra perusahaan, dan bahkan penurunan biaya usaha. Hal yang sama disampaikan oleh Jaffee \& Henson (2004), bahwa aspek finansial dari produsen cenderung lebih baik ketika berpartisipasi dalam standar privat. Dampak positif yang lain adalah dukungan teknis dan pelatihan dan peningkatan akses kredit ketika produsen berpartisipasi dalam standar privat (International Trade Centre, 2011). 
Namun demikian, penerapan standar privat memerlukan biaya sampai dengan proses sertifikasinya. Sehingga perlu diperhatikan dan dibandingkan antara keuntungan dari keberhasilan perdagangan dalam jangka panjang dengan beban biaya dalam penerapan standar privat tersebut. Hal ini sesuai dengan pendapat Jaffee \& Henson (2004) bahwa pendapatan yang meningkat tidak mengimbangi biaya tambahan dan peningkatan biaya tenaga kerja dalam memenuhi persyaratan standar privat tersebut merupakan salah satu dampak dan sisi negatif dari penerapan standar privat.

\section{KESIMPULAN}

Standar privat mempunyai pengaruh yang sangat kuat terhadap perdagangan global, hal ini didukung dengan semakin meningkatnya penerapan standar privat oleh konsumen dari negara tujuan ekspor. Pengaruh dari penerapan dan pemenuhan terhadap persyaratan standar privat adalah memberikan nilai tambah dan posisi tawar dalam perdagangan global sehingga dapat memberikan keuntungan bagi perusahaan. Keuntungan dari pemenuhan standar privat dapat maksimal apabila perusahaan mempunyai pengetahuan terhadap penerapan standar privat dari konsumen negara tujuan ekspor yang meliputi jenis standar sampai dengan cara sertifikasinya.

Pengetahuan ini perlu didukung oleh komitmen dari manajemen puncak dan kepedulian dari seluruh bagian perusahaan yang terlibat dalam rantai produksi produk. Penerapan atau implementasi standar privat harus dilakukan secara berkelanjutan untuk menjaga kualitas dan kesesuaian terhadap parameter standar privat tersebut. Biaya teknis dan non teknis dari penerapan standar privat perlu diperhatikan dan dibandingkan dengan keuntungan dari keberhasilan perdagangan dalam jangka panjang apabila suatu perusahaan bermaksud memasuki ceruk pasar yang didalamnya ada penerapan standar privat.

\section{UCAPAN TERIMAKASIH}

Ucapan terima kasih kami sampaikan kepada Pusat Penelitian dan Pengembangan Standardisasi - Badan Standardisasi Nasional yang telah membiayai penelitian ini melalui APBN Tahun 2016. Ucapan terima kasih juga kami sampaikan kepada anggota tim peneliti dan pihak-pihak yang mendukung penelitian ini.

\section{DAFTAR PUSTAKA}

Brunsson, N., \& Jacobsson, B. (2002). The Contemporary Expansion of Standardization. Oxford University Press: Oxford.

European Union External Action. (2010). Infrastruktur Kualitas Ekspor Indonesia. Brussels.

Fulponi, L. (2006). Final report on private standards and the shaping of the agro-food system.

Henson, S. (2008). The role of public and private standards in regulating international food markets. Journal of International Agricultural Trade and Development, 4(1), 63-81.

Henson, S., \& Humphrey, J. (2010). Understanding the Complexities of Private Standards in Global Agri-Food Chains as They Impact Developing Countries. Journal of Development Studies, 46(9), 1628-1646. https://doi.org/10.1080/0022038100370649 4

International Organization for Standardization. (2010). International standards and "private standards." Geneva.

International Trade Centre. (2011). The Impacts of Private Standards on Producers in Developing Countries. Geneva, Switzerland.

Jaffee, S., \& Henson, S. (2004). Standards and Agri-food Exports from Developing Countries: Rebalancing the Debate. Washington DC. https://doi.org/http://dx.doi.org/10.1596/181 3-9450-3348

Jati, G. P. (2017). Permudah Sertifikasi, Pemerintah Minta FSC Evaluasi Aturan. CNN Indonesia. Indonesia.

Kaplinsky, R. (2010). The Role of Standards in Global Value Chains.

Kementrian Perindustrian. (2016). Perkembangan Ekspor Indonesia Berdasarkan Sektor. Retrieved from http://www.kemenperin.go.id/statistik/peran. php?ekspor=1

Lambaga, A. (2009). Akselerasi Ekspor Produk Perikanan Indonesia Melalui Penerapan Standar. Prosiding Pertemuan Dan Presentasi IImiah Standardisasi.

Liu, P. (2009). Private standards in international trade: issues and opportunities. Geneva.

Mangelsdorf, A. (2011). The role of technical standards for trade between China and the European Union. Technology Analysis \& Strategic Management, 23(7), 725-743. https://doi.org/10.1080/09537325.2011.592 267 
Mc Cluskey, J. J. (2007). Public and Private Food Quality Standards: Recent Trends and Strategic Incentives. In J. F. M. Swinnen (Ed.), Global supply chains, standards and the poor: how the globalization of food systems and standards affects rural development and poverty (pp. 9-24). Oxon: CABI.

Putri, A. Y. (2010). Tinjauan Yuridis Pemberlakuan Standar Nasional Indonesia (SNI) Secara Wajib Berdasarkan Technical Barrier To Trade dan Good Regulatory Practice. Jakarta.

Resnia, R., Wicaksena, B., \& Salim, Z. (2015). Kesesuaian SNI Dengan Standar Internasional dan Standar Mitra Dagang Pada Produk Ekspor Perikanan Tuna dan Cakalang. Jurnal Standardisasi, 17(2), 8798.

Schuster, M., \& Maertens, M. (2015). The Impact of Private Food Standards on Developing Countries' Export Performance: An Analysis of Asparagus Firms in Peru. World Development, 66, 208-221.

Shepherd, B., \& Wilson, N. L. (2013). Product Standards and Developing Country Agricultural Exports: The Case of the European Union. Food Policy, 42, 1-10. https://doi.org/https://doi.org/10.1016/j.foodp ol.2013.06.003

Smith, D., \& Riethmuller, P. (1999). Consumer concerns about food safety in Australia and Japan. International Journal of Social Economics, 26(6), 724-742. https://doi.org/10.1108/0306829991022723 7
Spivak, S. M., \& Brenner, F. C. (2001). Standardization Essential, Principle and Practice. New York: Marcel Dekker Inc.

Sudjana. (2002). Metode Statistika. Bandung: Tarsito.

Sukesi, H., Suminto, Resnia, R., Mahatama, E., Nur, Y. H., \& Wicaksena, B. (2013). Kajian Kebutuhan StandardDalam Dimensi Daya Saing dan Perlindungan Konsumen. Jakarta.

Susanto, D. A., Isharyadi, F., \& Aliyah, N. (2016). Faktor-Faktor yang Mempengaruhi UKM Dalam Menerapkan Standar Secara Konsisten. Jurnal Standardisasi, 17(2).

Swann, G. M. P. (2010). The economics of standardization: An update.

Trienekens, J., \& Zuurbier, P. (2008). Quality and safety standards in the food industry, developments and challenges. International Journal of Production Economics, 113(1), 107-122. https://doi.org/10.1016/J.IJPE.2007.02.050

UNTAC/WTO. (2005). World Trade Report. Geneva.

Verman, L. C. (1973). Standardization: a new discipline. New Delhi, India: Archon Book.

Washington, S., \& Ababouch, L. (2011). Private standards and certification in fisheries and aquaculture (Current practice and emerging issues). Roma.

Yuwono, B., Zakaria, F. R., \& Panjaitan, N. K. (2012). Faktor-Faktor yang Mempengaruhi Penerapan Cara Produksi yang Baik dan Standar Prosedur Operasi Sanitasi Pengolahan Fillet Ikan di Jawa. Manajemen IKM, 7(1), 10-19. 
